\title{
Induction of Yeastlike Development in Aspergillus parasiticus
}

\author{
By R. W. DETROY AND A. CIEGLER \\ Northern Regional Research Laboratory (Northern Utilization Research \\ and Development Division, Agricultural Research Service, U.S. \\ Department of Agriculture), Peoria, Illinois 61604, U.S.A.
}

(Accepted for publication 21 December 1970)

\section{SUMMARY}

Vegetative development of Aspergillus parasiticus may follow either one of two patterns of morphogenesis (hyphal-yeastlike dimorphism) depending upon the presence or absence of manganese ions in the culture medium. The addition of exogenous amino acids, vitamins and other trace metals had no significant effect upon morphogenetic development or aflatoxin $B_{1}$ synthesis. The yeastlike forms are capable of continuous aflatoxin $B_{1}$ synthesis under non-proliferating conditions. Varying the $\mathrm{Mn}^{2+}$ concentration from $7 \cdot 3 \times 10^{-4}$ to $7 \cdot 3 \times 10^{-3} \mathrm{mM}$ causes a morphological change from yeastlike to hyphal development in a synthetic medium. The yeastlike forms are stable and resist osmotic shock.

\section{INTRODUCTION}

Vegetative development in many fungi shows duality of morphogenesis, known as mould-yeast dimorphism, in which the fungus may be in a filamentous form (hyphaltype) or a yeastlike form. Bartnicki-Garcia \& Nickerson (1962a) established that vegetative growth of $\mathrm{Mucor}$ rouxii may follow either one of these two patterns. A yeastlike development occurred upon anaerobic incubation under high tensions of $\mathrm{CO}_{2}$ (Bartnicki-Garcia \& Nickerson, 1962b). Vegetative morphogenesis was affected by the addition of metal chelating agents. Bartnicki-Garcia \& Nickerson (1962a) demonstrated that yeastlike development of $M$. rouxii was prevented by EDTA: however, this morphogenetic effect of EDTA could be reversed by transitional group metal ions. Wildman (1966) reported the occurrence of giant cells in small colonies of Aspergillus flavus Link grown upon an agar block.

In experiments dealing with the biosynthesis of aflatoxin $B_{1}$, we observed the appearance of spherical, yeastlike forms in the synthetic medium. However, these forms probably resemble arthrospores more than a true yeastlike phase since multiplication by budding was not observed (Bartnicki-Garcia \& Nickerson, 1962a). For convenience we have retained the use of the term 'yeastlike'. This communication presents information about induction of the yeastlike phase in cultures of Aspergillus parasiticus and compares the aflatoxin $B_{1}$-synthesizing ability of these forms to that of the filamentous form.

\section{METHODS}

Organism. Stock cultures of Aspergillus parasiticus NRRL 2999 were maintained on potato dextrose agar slants at $30^{\circ}$. Spores were harvested from 5 day slant cultures by covering the culture with sterile deionized water and brushing gently with an inoculation 
loop. The spore suspension was placed in sterile $500 \mathrm{ml}$. centrifuge tubes and centrifuged at $2000 \mathrm{~g}$. The spore pellet was washed with sterile water, filtered over a Millipore* filter, resuspended in sterile deionized water and shaken vigorously to break up clumps of spores. The spores were then counted in a haemocytometer. The suspension was used as the inoculum for liquid medium, care being taken to avoid variation in inoculum size due to sedimentation.

Cultural conditions. Three basal media were used. (I) Yeast extract+sucrose medium: sucrose, 200 g.; yeast extract, 20 g.; $\mathrm{MgSO}_{4} \cdot 7 \mathrm{H}_{2} \mathrm{O}, 0.5 \mathrm{~g} . ; \mathrm{ZnSO}_{4} \cdot 7 \mathrm{H}_{2} \mathrm{O}$, $0.005 \mathrm{~g}$.; $\mathrm{FeSO}_{4}, 0.01 \mathrm{~g}$., and distilled $\mathrm{H}_{2} \mathrm{O}$, I 1 . (2) Bacto yeast nitrogen base media (Difco) supplemented with $5^{\circ} \mathrm{O} \mathrm{g}$. glucose and diluted tenfold before use. (3) A synthetic culture medium: glucose, $50 \mathrm{~g}$.; $\left(\mathrm{NH}_{4}\right)_{2} \mathrm{SO}_{4}, 3.0 \mathrm{~g}$.; $\mathrm{KH}_{2} \mathrm{PO}_{4}, 10 \cdot 0 \mathrm{~g}$.; $\mathrm{MgSO}_{4}$. ${ }_{7} \mathrm{H}_{2} \mathrm{O}, 2.0 \mathrm{~g} ;\left(\mathrm{NH}_{4}\right)_{6} \mathrm{Mo}_{7} \mathrm{O}_{24} \cdot 4 \mathrm{H}_{2} \mathrm{O}, 0.5 \mathrm{mg}$; $\mathrm{Fe}_{2}\left(\mathrm{SO}_{4}\right)_{3} .6 \mathrm{H}_{2} \mathrm{O}, 0.3 \mathrm{mg}$. $\mathrm{CuSO}_{4} \cdot 5 \mathrm{H}_{2} \mathrm{O}$, $0.3 \mathrm{mg}$.; $\mathrm{ZnSO}_{4} .7 \mathrm{H}_{2} \mathrm{O}, 15.0 \mathrm{mg}$.; boric acid, $\mathrm{r} \cdot 0 \mathrm{mg}$., and distilled $\mathrm{H}_{2} \mathrm{O}$, I 1 . Various amino acids, vitamins and trace metals were added to the basal media in the concentrations indicated in the text. The various media were dispensed in $50 \mathrm{ml}$. volumes into $300 \mathrm{ml}$. Erlenmeyer flasks which were plugged with non-absorbent cotton wool and autoclaved at $12 \mathrm{I}^{\circ}$ for $15 \mathrm{~min}$. Each flask was inoculated with $3.2 \times 10^{6}$ spores and incubated at $30^{\circ}$ on a New Brunswick rotary shaker at $200 \mathrm{rev} . / \mathrm{min}$.

Analytical methods. Mycelia were harvested by filtration through previously dried and weighed Whatman no. 54I filter paper, dried for $2 \mathrm{~h}$. at $\mathrm{I} 10^{\circ}$, cooled and weighed.

Aflatoxin was extracted from the spentculture medium with chloroform. The chloroform extracts were evaporated to dryness in a flash evaporator, and the residue was redissolved in a known volume of $\mathrm{CHCl}_{3}$. The various aflatoxins were separated by preparative thin-layer chromatography on silica gel G-HR with $20 \%$ acetone in $\mathrm{CHCl}_{3}$ as developer. The aflatoxin $\mathrm{B}_{1}$ band was scraped off the plate, and the toxin eluted from the gel with methanol. Its concentration was measured spectrophotometrically (Nabney \& Nesbitt, 1964; Holzapfel, Steyn \& Purchase, 1966) at $362 \mathrm{~nm}$. with a Beckman-DB spectrophotometer.

Materials. All reagent-grade chemicals and chemical reagents, including amino acids, vitamins and trace elements, were purchased from commercial sources.

\section{RESULTS AND DISCUSSION}

Induction of yeastlike development. In preliminary experiments on the synthesis of aflatoxin $B_{1}$ in a defined medium under shake culture conditions, yeastlike forms of Aspergillus parasiticus almost completely replaced the normal hyphal form found in cultures supplemented with yeast extract. In the synthetic medium some yeastlike forms developed within $24 \mathrm{~h}$. of spore germination. After $72 \mathrm{~h}$. most of the culture was in the yeastlike phase. When yeast extract-sucrose (medium I) was added to this yeast-phase culture, mycelial forms developed from the yeast forms. The importance of a nutrient in yeast extract that was required for induction of the hyphal growth phase was then investigated, as well as other possible deficiencies in the synthetic medium which may have been responsible for the formation of the yeastlike forms.

Effect of vitamins, metal ions and amino acids. In the preliminary experiments three amino acids (histidine, methionine, tryptophan), five metal ions ( $\mathrm{Zn}, \mathrm{Mo}, \mathrm{Fe}, \mathrm{Cu}, \mathrm{Mn}$ )

\footnotetext{
* The mention of firm names or trade products does not imply that they are endorsed or recommended by the Department of Agriculture over other firms or similar products not mentioned.
} 
and nine vitamins (biotin, pantothenate, folic acid, inositol, niacin, para-aminobenzoic acid, pyridoxine, riboflavin, thiamin) were added separately and in various combinations to the basal synthetic medium and their effect upon morphogenesis was observed at various intervals after inoculation. Yeastlike forms developed only in the absence of added $\mathrm{Mn}^{2+}$ ion; $\mathrm{Mn}^{2+}$ at $7.3 \times \mathrm{IO}^{-1} \mathrm{mM}$ yielded hyphal forms of the organism. The absence of all the metal ions from the basal synthetic medium resulted in either no or scant growth.

Table I. Effect of $\mathrm{Mn}^{2+}$ concentration upon the morphology of Aspergillus parasiticus cultured in synthetic medium

$\begin{array}{ccc}\mathrm{Mn}^{*}(\mathrm{mM}) & \overbrace{\text { Hyphal }}^{\text {Morphology }} & \text { Yeastlike } \\ 0 & - & + \\ 7.3 \times 10^{-5} & - & + \\ 7.3 \times 10^{-4} & - & + \\ 2.0 \times 10^{-3} & + & + \\ 7.3 \times 10^{-3} & + & - \\ 7.3 \times 10^{-2} & + & - \\ 7.3 \times 10^{-1} & + & - \\ \mathrm{Mn}^{2+} \text { added as } \mathrm{MnCl}_{2} \text { to the basal synthetic medium. }\end{array}$

Effect of manganese concentration. The responses to various concentrations of $\mathrm{Mn}^{2+}$ in the medium are shown in Table $\mathrm{I}$. The cultures were almost entirely in the yeastlike form in the absence of $\mathrm{Mn}^{2+}$ or when $\mathrm{Mn}^{2+}$ was added up to $7.3 \times 10^{-4} \mathrm{mM}$; higher $\mathrm{Mn}^{2+}$ concentrations gave the hyphal form. The different concentrations of $\mathrm{Mn}^{2+}$ had no significant effect upon total cell yield or aflatoxin $B_{1}$ synthesis.

Morphological development of Aspergillus parasiticus. The first morphological development of the spores was germ-tube formation, which occurred after 20 to $24 \mathrm{~h}$. in the $\mathrm{Mn}^{2+}$ deficient synthetic medium. The first signs of morphological change was a protrusion or swelling of the young vegetative hyphae at $48 \mathrm{~h}$. (Pl. I, fig. I). These protrusions were found either at hyphal tips or randomly distributed along the length of hyphae (Pl. I, fig. 2). Subsequently these bodies swelled into large spherical, yeastlike forms between 75 and $90 \mathrm{~h}$. growth (Pl. I, fig. 3). Further incubation up to $185 \mathrm{~h}$. gave pellets composed almost totally of yeastlike growth. This yeastlike form appeared to be a stable, morphogenetic form of Aspergillus parasiticus (P1. I, Fig. 4).

The addition of $7.3 \times 10^{-1} \mathrm{~mm} \mathrm{Mn}^{2+}$ to a synthetic medium containing spores resulted in normal germination and outgrowth throughout development of the culture, producing the hyphal form. Noyeastlike forms could be detected under these conditions.

Cultivation of this organism upon agar slants containing the synthetic nutrients minus $\mathrm{Mn}^{2+}$ also yielded the yeastlike form of growth.

Manganese appears to be a multifunctional metal in the metabolism of numerous fungal and bacterial systems. It is involved in cell wall synthesis, as well as in DNA, RNA and fatty acid biosynthesis (Hoffman, Scheck \& Saffert, 1950; Fox \& Weiss, 1964; Jirgena, 1967; Oka, Udagawa \& Kinoshita, 1968). Although no evidence is available concerning the effect of $\mathrm{Mn}^{2+}$ deficiency upon wall constituents in Aspergillus parasiticus, production of yeastlike forms possibly may occur via an incomplete or altered wall-synthesizing mechanism. There appears to have been a lack of protein 
synthesis after $85 \mathrm{~h}$. in a $\mathrm{Mn}^{2+}$-deficient medium because transfer of yeastlike forms to fresh synthetic medium (lacking $\mathrm{Mn}^{2+}$ ) led to no further growth or protein synthesis but growth recommenced on the addition of sufficient $\mathrm{Mn}^{2+}$ to such a culture. These observations suggest that in the manganese-deficient medium the organism utilized the available endogenous $\mathrm{Mn}^{2+}$ in the spores for germination but that this $\mathrm{Mn}^{2+}$ was not sufficient to support hyphal morphogenesis. This $\mathrm{Mn}^{2+}$ deficiency might then have inhibited enzyme activities required for wall synthesis and eventually arrested primary metabolism, such as protein, DNA and RNA synthesis systems.

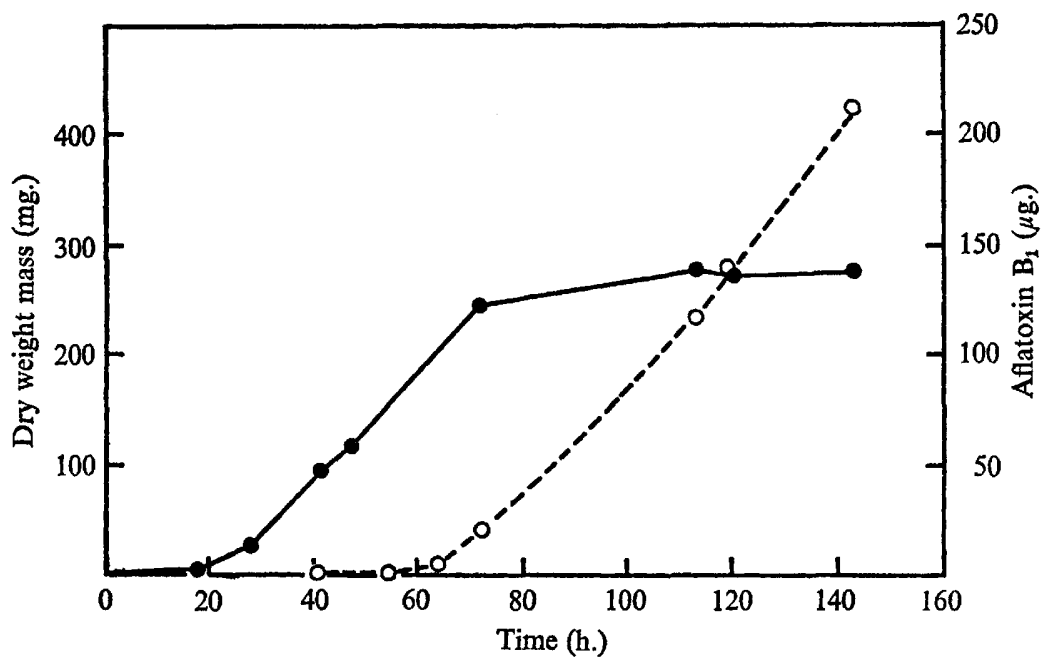

Fig. 1. Growth and aflatoxin $\mathrm{B}_{1}$ synthesis by Aspergillus parasiticus growing in a synthetic medium. Results are expressed as mg. dry wt/culture flask and $\mu \mathrm{g}$. aflatoxin $B_{1}$ produced. - , Mass (mg. dry wt) yield; $\mathrm{O}-\mathrm{O}$, aflatoxin $\mathrm{B}_{1}$ synthesis.

Comparison of aflatoxin $B_{1}$ synthesis by hyphal and yeastlike forms. The synthesis of aflatoxin $B_{1}$, a potent hepatocarcinogen (Wogan, 1969), by hyphal and yeastlike forms of Aspergillus parasiticus in various media was investigated. The yeastlike form in $\mathrm{Mn}^{2+}$-deficient synthetic medium began to synthesize just before the growth rate began to decrease (Fig. I); this stage of culture is termed the secondary phase or idiophase of growth (Bu'Lock et al. 1965). Toxin synthesis continued to increase until the $\mathrm{pH}$ reached $2 \cdot 5$ to $2 \cdot 3$.

The addition of $\mathrm{Mn}^{2+}$ before spore germination resulted in development of the hyphal form only and a slight delay in aflatoxin synthesis. The presence of $\mathrm{Mn}^{2+}$ ion at concentrations sufficient to support growth of the hyphal form had no appreciable effect upon total toxin synthesis by either the yeast or hyphal forms.

When the yeastlike forms were transferred to fresh synthetic media, they were incapable of further replication or increase in total cell mass. However, aflatoxin synthesis recommenced until again limited by the drop in $\mathrm{pH}$ of the medium. These yeastlike forms could be transferred every 24 to $48 \mathrm{~h}$. to fresh synthetic medium for continuous production of aflatoxin $B_{1}$. Cells were still capable of toxin synthesis after being transferred over a period of 30 days, at which time the experiment was ended.

Growth of the organism in yeast extract + sucrose medum resulted in high yields of 
the hyphal form and of aflatoxin (Fig. 2). In this medium slowing of vegetative growth was followed by the onset of toxin synthesis. Growth of Aspergillus parasiticus was sparse on Bacto yeast nitrogen base media, yielding only I $10 \mathrm{mg}$. of mycelial dry weight in the hyphal form. Not only did aflatoxin synthesis fail to occur, but also many of the spores failed to germinate. This medium contained all the necessary vitamins, amino acids and trace metals usually required for growth of many fungi.

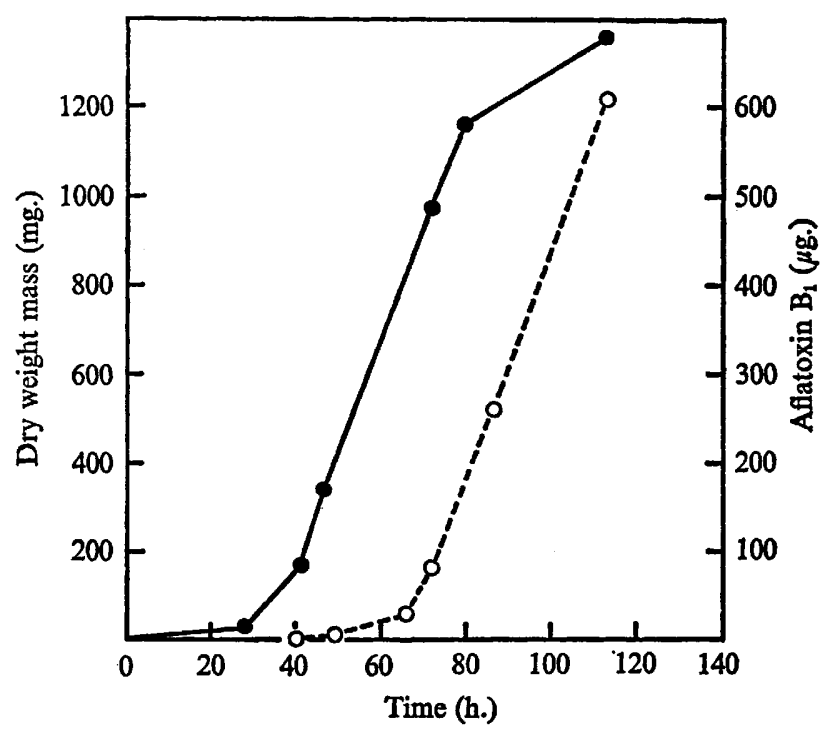

Fig. 2. Growth and aflatoxin $\mathrm{B}_{1}$ synthesis by Aspergillus parasiticus growing in a yeast extractsucrose medium. Results are expressed as $\mathrm{mg}$. dry wt/culture flask and $\mu \mathrm{g}$. aflatoxin $\mathrm{B}_{1}$ produced.

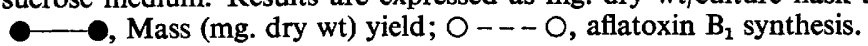

Characteristics of yeastlike forms. The yeastlike form of Aspergillus parasiticus were resistant to lytic enzymes and osmotic shock. If the yeastlike form arose through either the incomplete synthesis of hyphal wall or through an altered wall synthesis, it would possibly be more susceptible to osmotic shock or enzymic lysis. This hypothesis was tested by incubating the yeastlike forms in $0.75 \mathrm{M}$ sorbitol and $0.5 \mathrm{M}-\mathrm{NaCl}$ for a $20 \mathrm{~h}$. incubation period followed by suspension in distilled water. The yeastlike forms were harvested and observed microscopically for breakage. The majority were intact with little evidence of cellular destruction. Since cell walls of most fungi contain lipid, polysaccharide and cellulose or chitin, the yeastlike forms were treated with chitinase, lipase, lipoxygenase and cellulase enzymes but no hydrolysis resulted.

Upon transfer of yeastlike forms to a synthetic medium containing $\mathrm{Mn}^{2+}$ further growth produced filamentous, hyphal forms, which indicated again the need for $\mathrm{Mn}^{2+}$ for formation of hyphal mycelial.

The capable technical assistance of Melba S. Milburn is gratefully recognized. 


\section{REFERENCES}

BartNicki-Garcia, S. \& Nickerson, W. J. (1962a). Induction of yeastlike development in Mucor by carbon dioxide. Journal of Bacteriology 84, 829-840.

BARTNICKI-GARCIA, S. \& NICKERSON, W. J. (1962 b). Nutrition, growth, and morphogenesis of Mucor rouxii. Journal of Bacteriology 84, 841-858.

Bu'Lock, J. D., Hamilton, D., Hulme, M. A., Powell, A. J., Shepherd, D., Smalley, H. M. \& SMITH, G. N. (1965). Metabolic development and secondary biosynthesis in Penicillium urticae. Canadian Journal of Microbiology $11,765-778$.

Fox, C. F. \& WeIss, S. B. (1964). Enzymatic synthesis of ribonucleic acid. II. Properties of the DNAprimed reaction with Micrococcus lysodeikticus RNA polymerase. Journal of Biological Chemistry 239, $175-185$.

HofmanN, E., SCHECK, H., \& SAFFerT, K. (1950). Influence of manganese on the formation of sucrase, $\beta$-glucosidase and catalase in Aspergillus oryzae. Biochemische Zeitschrift 320, 126-135.

Holzapfel, C. W., STEYN, P. S. \& PURChase, I. F. H. (1966). Isolation and structure of aflatoxins $\mathrm{M}_{1}$ and $\mathrm{M}_{2}$. Tetrahedron Letters 2799-2803.

JIRGENA, A. (1967). Effect of trace elements vanadium, cobalt, manganese, and copper on the lipid metabolism in yeast cells. Latvijas Padomju Socialistiskas Republiskas Zinatnu Akademijas Vestis 6, 82-87. (In Latvian.)

NabNEY, J. \& NesBITt, B. F. (1964). A spectrophotometric method for determining the aflatoxins. The Analyst 90, $155-160$.

Nadson, G. \& Philippov, G. (1925). Une nouvelle mucorineé. Mucor Guilliermondii, n. sp. et ses formes levures. Revue Générale de Botanique 37, 450-461.

Nickerson, W. J. \& EDWARDS, G. A. (1949). Studies on the physiological basis of morphogenesis in fungi. I. The respiratory metabolism of dimorphic pathogenic fungi. Journal of General Physiology 33, 4I-55.

OKa, T., UdAGAwa, K. \& Kinoshita, S. (1968). Unbalanced growth death due to depletion of $\mathrm{Mn}^{2+}$ in Brevibacterium ammoniagenes. Journal of Bacteriology 96, $1760-1767$.

SteVENS, A. \& HeNRY, J. (1964). Studies of the RNA polymerase from E. coli. Journal of Biological Chemistry 239, 196-203.

WAKIL, S. J. (1962). Lipid metabolism. Annual Review of Biochemistry 31, 369-400.

WIIDMAN, J. D. (1966). Note on occurrence of giant cells in Aspergillus flavus Link. Journal of the Association of Official Analytical Chemists 49, 563-564.

Wogan, G. N. (1969). Naturally occurring carcinogens in foods. Progress in Experimental Tumor Research Ix, I34-163.

\section{EXPLANATION OF PLATE}

Fig. I. Swelling of young hyphae of Aspergillus parasiticus in submerged culture, growing in synthetic medium (minus $\mathrm{Mn}^{2+}$ ). $\times 800$.

Fig. 2. Swelling and protrusion of the hyphal tips of $A$. parasiticus in submerged culture, growing in synthetic medium (minus $\mathbf{M n}^{2+}$ ). $\times 800$.

Fig. 3. Development of complete spherical yeastlike bodies of $A$. parasiticus in submerged culture, growing in synthetic medium (minus $\mathrm{Mn}^{2+}$ ). $\times 800$.

Fig. 4. Mature yeastlike forms of A. parasiticus in submerged culture, growing in synthetic medium (minus $\mathrm{Mn}^{2+}$ ). $\times 800$. 

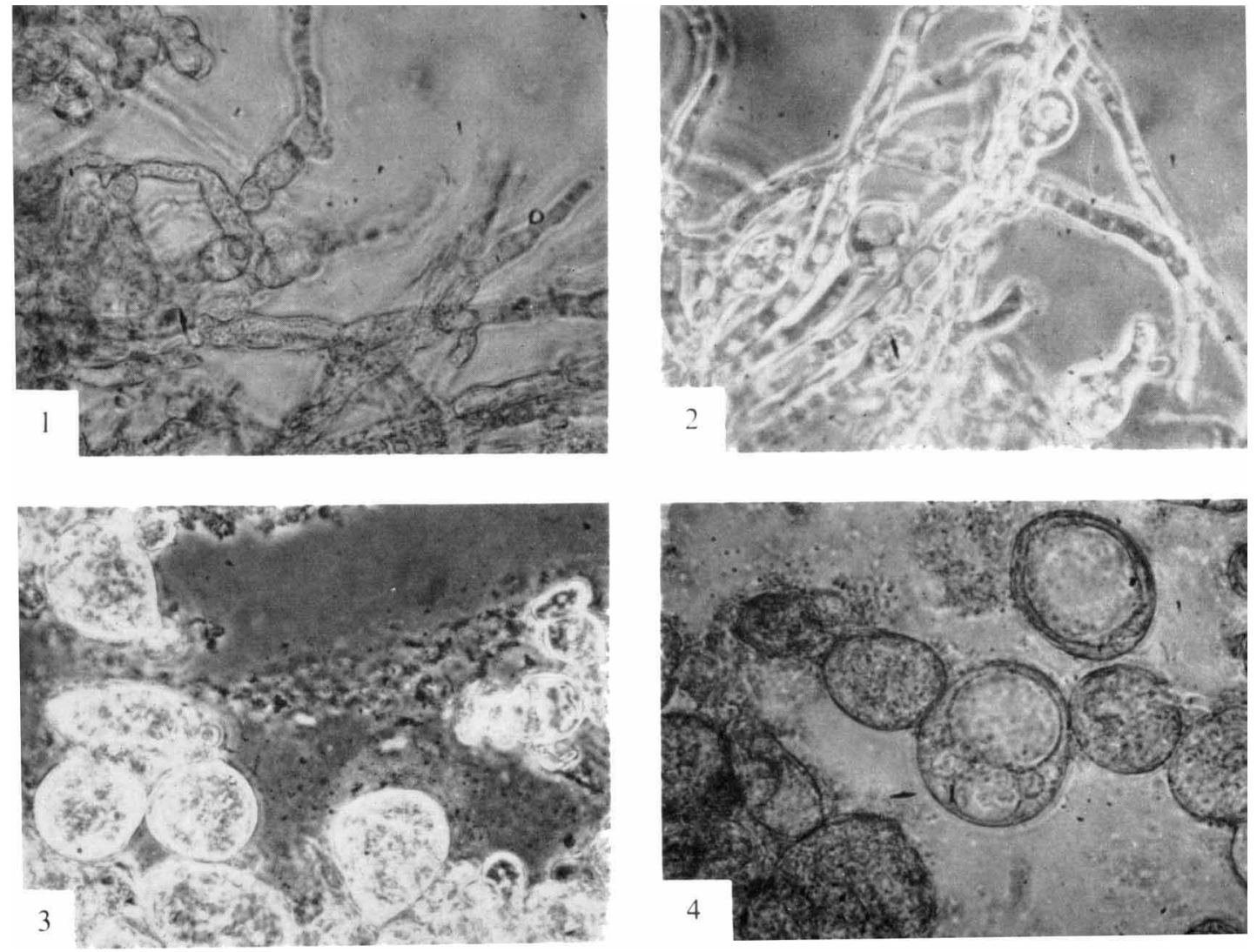